\title{
ARE WE WHAT WE BUY AND WHAT WE CONSUME?: CRISIS OF IDENTITY IN HANIF KUREISHI'S THE DECLINE OF THE WEST
}

Ali Gunes

Karabuk University, Turkey

\section{Abstract}

This paper explores in Hanif Kureishi's short story The Decline of the West the harsh economic recession or what he calls in the story "a financial crash" and its inevitable crippling negative impact on the social life in general and on individual life in particular, especially in the wake of the collapse of Wall Street back in 2008, which has obviously changed the way of living for millions of people across the world, specifically in Western societies in Europe and North America. In so doing, the paper is divided into two parts. In the first part, it debates that the capitalism as an economic system has radically transformed not only the traditional commercial and financial system, but it has also given rise to the construction of consumption culture, which has eventually altered the ways people across the world used to live, together with their perception of life and identity. This view of identity has closely been related to personal happiness, satisfaction, comfort, and freedom, along with the social status and prestige in one's life. As the second part of the paper argues, however, this view of identity has faced far-reaching crisis in the wake of the economic downturn since 2008 as represented in the life, view and identity of Kureishi's fictional character Mike in the story after he is fired from his job in a bank. Having lost his job, Mike finds himself financially unable to keep his personal material comfort and satisfaction, meet the demands of his family and maintain his social status and prestige as in the past. Hence his sense of self and stability falls apart; he loses his soul, as well as his vision of "the future" and eventually wants to "die" to rid of his psychological frustration and chaos.

Key words: Capitalism, consumer culture, materialism, financial crisis, identity 
This paper explores in Hanif Kureishi's short story The Decline of the West (2010) the harsh economic recession or what he calls in the story "a financial crash", along with its inevitable crippling negative impact on the social life in general and on individual life in particular, especially in the wake of the collapse of Wall Street or global financial crisis during 2007-2008, which has obviously changed the way of living for millions of people across the world, specifically in Western societies in Europe and North America. In doing so, the paper is divided into two parts. In the first part, it debates that the capitalism as an economic system has radically transformed not only the traditional commercial and financial system since the Industrial Revolution in the eighteenth century, but it has also given rise to the construction of consumption culture, which has eventually altered the ways people across the world used to live, together with their perception of life. This perception of life has closely been related to personal happiness, material satisfaction, comfort, freedom and more choices, as well as to the social status or prestige in one's life: that is, this view of life has become a lifestyle, a way of living, an identity thoroughly associated with the level of prosperity and possession in the postmodern period. In its second part, however, the paper argues how this view of identity has faced far-reaching crisis in the wake of the economic downturn since 2007 as represented in the life, view and identity of Kureishi's fictional character Mike in The Decline of the West after he is fired from his job in a bank. Having lost his job, Mike finds himself at once financially unable not only to keep his personal material comfort and satisfaction and maintain his social status and prestige but also to meet the demands of his family as in the past. Once he finds himself incapable of upholding his level of "buying" and "spending" power, therefore, Mike feels insecure and lost, so that his sense of stable self falls apart, and he loses psychologically both his soul and firm ground under his feet, as well as his vision of "the future", and eventually he wants to "die" to rid of his psychological disturbance and frustration and chaos (Kureishi, 2010, p. 405).

Consumerism, unquestionably entwined with capitalism, is one of few crucial issues which visibly affects the daily life in the postmodern society, constantly shaping and re-shaping social structures and institutions, along with habits, perceptions and identities by imposing its hegemonic and controlling grip on individuals and group lives and behaviours(Lasch, 1979; Smith, 1986; McKibben, 1989; Suzuki , 1997; Baudrillard, 1998; Beaud, 2001; Emerald, 2004; Malpas, 2005; Dittmar, 2007a; Todd, 2012; Chotiudompant, 2013 and Jansiz, 2014). As OED defines it, consumerism is an act of "the buying and using of goods and services" or "the belief that it is good for a society or an individual person to buy and use a large quantity of goods and services" (2010, p. 312). For Encyclopaedia of Science, Technology, and Ethics, it is "a way of life combining high level of material affluence with an emphasis on symbolic and emotional meanings associated with shopping and possessions" 
(2005, p. 538; emphasis added). Douglas and Isherwood (1996) succinctly describe consumerism as the possession of a product for the purpose of meeting certain needs as well as a part of social system which explains the desire to work for retaining goods with the aim of forming a relationship with other people in society (Qtd in Jansiz, 2014, p. 78). Finally, Suradech Chotiudompant (2013) argues that "consumerism is a crucial issue nowadays because we need to consume not only to meet our basic needs but also to satisfy our wants, which are increasingly complex and hard to distinguish from the former. We need to consume...to create our identity, to state our political standpoint or to quench our insatiable desires" (p. 83; emphasis added). As seen in these definitions and arguments above, consumerism in the first place is merely linked to the satisfaction of basic material needs and demands of everyday life in which individuals simply buy and consume certain goods and use services as part of their daily lives and in which individuals basically also tend to accumulate material goods for the future to secure their lives. In this respect, consumerism is simply defined and shown as an inevitable act and part of life in its normal routine way to sustain life activities by meeting our basic needs, along with satisfying our desires in life.

However, as the critics above and many others elsewhere point out, consumerism is not a naïve activity or issue in life to deal with in its ostensible meaning but has deep social, cultural, and ideological meanings generated by capitalism particularly as for the identity politics and formation because the "high level of material affluence" with its "symbolic and emotional meanings associated with shopping and possessions" on both social and personal levels is clearly identified not only with the material standing of a particular society but also with the lifestyle and way of life of an individual personal (Fromm, 1978; McCracken, 1990; Rose, 1996; Arnould and Thompson, 2005; Vignoles, Regalia, Manzi, Golledge, and Scabini, 2006; Kasser and Kanner, 2004; Malpas, 2005 and Dittmar, 2007b).Consumerism or consumer culture, which is very much stimulated by capitalist economic system worldwide through various means of communications such the advertisements such as TV, mass media, billboards, internet, online-shopping and so on, obviously bombard us every day to buy and consume commodities more and more by creating an interactive relationship in the markets: we depend on the commodities in the market just as much as the commodities in the market depends on us as individuals. In this inseparable relationship, what we buy and consume eventually shapes our way of life, organize our lifestyle, perception of life and our world view, as well as our social status and prestige in the late capitalist mass consumer period even sometimes beyond our knowledge and control, so that goods and services that we purchase and use give shifting and constant new meanings to our life and make us feel good and happy in our daily lives (McKibben, 1989; Cook, 1992; Andersen, 1995; Suzuki, 1997 and Cross, 2000). As for this "symbolic" and ideological meanings behind consumerism, 
which obviously create a sense of who we are, for example, James B.

Twitchell (2002) argues that "The one unambiguous result of modern capitalism, of the industrial revolution, and of marketing...is: In the way we live now, you are not what you make. You are what you consume" (p. 1).Moreover, Danielle Todd (2012) also sees a profound relationship between consumerism and identity politics and formation which, she argues, is firmly "tied to the creation and production of a sense of self", and for her, "products are imbued with a greater significance than what their primary function may be." In her view, "Today, it is virtually impossible to buy any product not embedded with certain symbols of identity acquired by the buyer knowingly or otherwise. Recognizing this, it is possible to draw the conclusion that consumption functions as a way to create a sense of self" (p. 48). In The Consumer Society, finally, Jean Baudrillard (1998) regards consumerism as the system of sign in the Saussurian and Lacanian sense or as a kind of motivation that he argues has its own language or code in which the identities of postmodern consumers are programmed and constructed without being sometimes conscious and sometimes unconscious of this "language" and "code":

The circulation, purchase, sale, appropriation of differentiated goods and signs/objects today constitute our language, our code, the code by which the entire society communicates and converses. Such is the structure of consumption, its language, by comparison with which individual needs and pleasures are merely speech effects (pp. 79-80).

This quotation clearly tells us that commodities we buy and the way we use them are not just simple products but they have their own "language" and "code" which allows us to communicate with the outside world and vice versa, in which we are located into the pool of various complex meanings and relationships through the way we purchase and the way we consume. In the first place, how we are seen by the outside society is, in fact, decided and constructed as in the symbolic order of Lacan by the "language" and "code" of "goods" which we buy and consume, yet in this process, the great truth behind the "language" and "code" of "goods" is never told, but the "language" and "code" of "goods" knowingly or unknowingly construct us as subjects in a way that we get used to leading this kind of life in time. Hence there seems no escape from the "language" and "code" of "goods", as well as from their untold own ideology always imposed on consumers.

In the second place, what is suggested in the quotation above is that consumption on the personal level creates a sense of who we are and thus is closely bound up with our innermost desires and "pleasures" as in the Freudian pleasure principle: the continuous pursuit of pleasure and happiness in the commodities we buy and consume in our daily lives. What we consume causes us to feel ourselves personally in different ways. The goods we consume, the clothes we wear, the house we own, and the car we drive visibly touch our subconscious realm - feeling, emo- 
tion and aspiration - and thus influence the way we feel and act. Such a feeling boasts our subconscious desires and gives us a sense of identity in which we perceive the life in accordance with what we purchase and what we spend. In this view of identity, there is always stimulating to spend more and more to remain in the intensity of happiness and satisfaction. These commodities become part of us and vice versa. As Baudrillard (1998) argues, therefore, the postmodern consumer is apparently placed under the influence of such a feeling into an "array of sham objects, of characteristic signs of happiness, and then waits ... for happiness to alight' (p. 31).

Likewise, "sham objects" also become the source of "happiness" and "pleasure" for Mike in Kureishie's The Decline of the West. He represents Mike in a way that he acts in line with the demands of capitalism and consumer culture, in which he immensely enjoys the power of "buying" and "using goods". Simply, Mike's philosophy of life is that "Everyone should have what they want whenever they want it" (Kureishi, 2010, p. 407). Since he is working for a bank and makes good money, therefore, Mike noticeably becomes able not only to meet his own personal and family needs and make himself and family comfortable and happy whenever he wants but also to achieve a kind of social standing and prestige that position him at once into a discernible social situation where he is given an identity and place as an individual by the others outside. What is of vital importance for Mike with his material affluence in the late capitalist period is to keep his current level of unavoidable power of buying and consumption in which he will able to manage to continue personal happiness, satisfaction, and freedom and keep his good social standing and esteem in his life. That is, Mike has ideologically been taught by the postmodern economic system and consumer culture in the 1980s and 90s that "capitalism was flourishing and there was no finer and more pleasant way to live but under it, signing and spending” (p. 404; emphasis added).

In The Decline of the West, Mikeworks for a bank. He has a good job and makes good money, even though he, aged 45, works twelve hours every day. The money he earns avails him of opportunity to lead a luxurious, comfortable material life, a life in which he is able to satisfy not only his own basic needs but also that of his family in line with the demands of consumer culture in the early decade of the twenty-first century. As soon as the story opens, the reader is immediately given the impression about the life Mike and his wife Imogen lead. Once he arrives home in the prosperous outskirts of London from his job in the bank, for example, Mike is always used to looking forward to "the door into the warm hall, hearing voices of his wife and children, and seeing that the cat come down the stairs to rub itself against him" (p. 401). He has a five-storey house with "off-street parking, overlooking a green" (p. 401), and also he, together with wife, has decorated a "hyper-shiny dining-room table where he liked to have supper and talk with his friends" in their 
spare times (p. 402). In addition to this, Mikeis "seriously planning more work on the garden as well as the rest of house", and he had already built "a shed" for "the boys to play music in, fitted with a TV, drum-kit and sound system" (p. 402). Moreover, why Mike urgently desires to enlarge his garden has two reasons. First, "As [Mike's] boys liked to point out, other children at their schools lived in bigger places; their fathers were the bosses of record companies or financial advisors to famous footballers. Mike, in corporate finance, was relatively small-time," and secondly, his friends have been constantly "improving their properties. It was a natural law: you never lost money on a house" (p. 402). As seen in the quotations above, having a comfortable and luxurious house evidently stands for personal material power, happiness and satisfaction. Hence it is this stimulation that psychologically forces him to go ahead and expand the scope of what makes him and his family happy and satisfied in their lives. What is more, these quotations also suggest that there is an implicit social and ideological pressure on Mike and his children in that he strives to give a message to the outside world about his identity and social standing that he has enough material power and affluence to accommodate himself properly into an acceptable place in his social and cultural environment. As in the Marxist world view, it is the spirit of time - social, cultural and political factors - which knowingly or unknowingly constructs the human identity, and thus Mike feels himself obliged to carry out what is socially, culturally and ideologically demanded of him in the early decade of the twentieth-first century: that is, he should achieve "continuous material improvement" (p. 404).

As for Mike's social material position, another sign of "continuous material improvement" in The Decline of the West is that his two sons - Tom and Billy-are part and product of consumer culture. Their education and the goods they demand give an idea about the family's material position, and Kureishi portraits them in a way that they become representatives of almost all the children across the world today. Mike's sons are "attending private schools" (p. 404), which puts him and his children at once into a different but higher social status achieved by Mike's level of earning and consumption because today not many families are able to afford to send their children to "private schools" in the world. "As well as attending private schools", Mike's sons also take "tennis, Spanish, piano, swimming, signing and karate lessons" in accordance with their status, and they, like children of well-off families, "frequently attended the cinema, the theatre and football matches" (p. 2). Given the fact that private education institutions have dramatically increased, along with the increase in the number of their students in recent years across the world, the situation of Mike's children is not surprising and unusual but part of the general state of affairs in the postmodern era. In order not to fall behind other children around him, Mike feels it necessary to participate in the competition for the education of his children. Sending children to "private schools" sometimes overtly and sometimes cov- 
ertly means good education and then good job in the future, so that many families tend to send their children to "private schools", even though it requires hard work and a respectable amount of income and material wealth to achieve this purpose. However, the deep meaning and implication behind is that the education at "private schools" also illuminates the power of money and spending of a particular family associated with its social identity, position and prestige because "private schools" become a sign of who Mike is; he is judged and categorized in a way that he is different from the others, who are unable to send their children to "private schools". Finally, the demands of Mike's sons never end. Like children of many contemporary families, they are in a music band and thus want to take the "guitar lesson", yet they first need "guitar, an amp and a microphone"(p. 407).As seen in these quotations above, what Mike, now unemployed, is required to do for his sons entails the material affluence and consumption, yet all these objects - "private school", "guitar lesson", "guitar, an amp and a microphone" - have their "language" and "code" in the Baudrillardian sense which give an ideological and cultural message to the outside world about Mike's lifestyle and identity, along with that of his sons.

It is not only Mike's sons who enjoy a luxurious life but also his wife Imogen who also becomes a sign and "language" of high material standard through her life style in The Decline of the West. As soon as the story begins, Imogen immediately gives the reader an impression as if she was a queen and had servants at her service all round to clean her house and cook for her. First, she is seen in the hall as "carrying gin and tonic", and the reader learns that she is used to having "bath" everyday as part of her life at home (p. 401). Moreover, the narrator tells us that Imogen has "never knowingly ingested anything non-organic" (p. 402), and she always "appeared to dress in diamonds and gold when at lunch with her friends" (p. 406) and continuously asks her husband for "a new computer" (p. 407). As seen in these quotations above, Imogen is different from a traditional woman who had satisfied herself with what she had, who had not been demanding and who had led a normal simple life, yet Imogen's life apparently seems comfortable, luxurious and expensive, and she seems to have been captivated by this kind of life. Without a certain level of money, the life she leads is not possible. Not only does it require money and material prosperity, but it also entails continuous spending or consumption.

Having taken all these quotations above into consideration, Mike, as an annoying sculptor in The Decline of the West refers to, is "the cult of money" (p. 404): he earns money and spends it extravagantly. It is what he is culturally and ideologically required to do by capitalist consumer culture: in the eyes of an annoying sculptor, Mike is what he earns and what he spends. Mike's way of life and worldview, together with that of his family, have been shaped very much by this culture, which has constantly inculcated them with an idea that "there was no finer and 
more pleasant way to live but under it [capitalism], signing and spending." Under this perception of life, Mike and his family members have continuously desired to improve further their material affluence and conditions not only to satisfy their basic material needs but also to retain their social position as culturally and ideologically requested by the postmodern world view. This shiny and luxurious lifestyle is very colourful, talismanic and captivating, and what Mike buys and how he consumes is obviously imbued with a greater significance than their primary meanings and functions may be. That is, the way he purchase and the way he consumes function as a means to create a sense of Mike's self, in which he is called "the cult of money", or he just calls himself "the Delivery man" (p. 407). These attributions evidently form Mike's worldview and the identity assigned to him, and he, like many of us, is just a mechanical money-making machine, which replaces his true spiritual identity inside. As for this view of identity, Adem Caylak (2011, December 12) argues that "the production relationship of capitalism and the system of its values regard everything in life from the materialistic point of view and [thus] ignores what should dominate human life - morality and virtue", and in such a system of relationship, he continues to state that "being just and good is not given priority; instead, earning much money and attaining power are accepted as success in today's world." In such a view of identity, Mike is nothing but the one who helps capitalism to sustain and further improve its existence in an enthralled way because the level of consumption is, in fact, the measure of the economic system - his value is what we buys and consumes. In addition, as in Baudrillard's words above, each goods Mike buys and each activity he conducts become "signs", "codes", and "language" or what I call an ideology by which he communicates with the larger outside world; he gives the outside world different messages where he fits with the social, cultural and political structure of the outside physical world. Besides, whether or not they are aware of it, the identities of Mike and his family members are also very much constructed and controlled by the capitalist consumerist lifestyle, so that Mikeis psychologically, culturally and ideologically shown and mesmerized in the 1980s/90s that "capitalism was flourishing and there was no finer and more pleasant way to live but under it, singing and spending" in the globalized postmodern world.

However, this "finer and more pleasant way to live" under capitalism by "singing and spending", gets into serious trouble at once when "capitalism was cracking under the weight of its contradictions as the Marxists had predicted", and Kureishi radically questions the view of the fragile identity constructed by the forged perception of capitalism and of its ingrained consumer culture through the life and views of Mike in The Decline of the West: that is, "If there was no comfort, what then were consolations of capitalism?" (Kureishi, 2010, p. 408)For the continuation of their existence, as seen here, capitalism and consumer culture had to advertise and propagate implicitly the ideology of "comfort" to show that the capitalist eco- 
nomic system was able to achieve a constant stable growth, low unemployment and low inflation, which would have made individuals happy, comfortable, and prosperous in their lives. Hence it is obvious today and represented in the story that this ideology has gradually become in time a way of life and eventually a view of identity, forcing individuals unconsciously to buy and consume goods more and more so as to be comfortable and happy in their lives, even though sometimes they did not need to do so. Thus, Kureishi illuminates in his short story how this perception of ideology or way of life and identity Mike has experienced excessively so far in his life are, in fact, false, lie, fragile and vulnerable. Mike eventually comes to realize this fact once he is fired from his job in the bank and forsakes almost everything behind: that is, the promise of constant stability by capitalism has been a big veiled lie.

Indeed, there is a close relationship between the dismissal of Mike from his job in the bank and the financial crisis which took place in 2007/8 with a wave of bank nationalisations across North America and Europe possibly due to international trade imbalances, the higher credit rate, the deterioration in export earnings and weak stock markets, lax lending and so on (Wolf, 2010; Sorkin, 2010; Stigliz, 2010; Peters, 2012). This financial crisis, though it had started mainly in North America and Europe, has eventually turned into a global financial crisis, throwing economies around the world into a great recession since the Great Depression of the 1930s (Wolf, 2007; Reinhart and Rogoff, 2009). Among many crippling negative impacts of this recession on the economics around the world are deep uncertainties, panic and worry about the future, yet what has been alarming for some time is the sharp increase in the rate of unemployment after many employees across the world had been sacked from their jobs, leading them not only to lose their proper income but also to be deprived of their power of "buying and spending", which had given them a sense of who they are in the capitalist market economy. Eventually, there has been a major shock to the consumer culture, which not only sustains the capitalist economy on track but also gives an impression to the consumers that the economy is moving steadily in its stable way. This economic slump was also a blow to the identity because consumer culture had often propagated through various means of advertisements the view that there has been close relationship between money and identity or between the "buying and spending" power and identity since the advent of the capitalist economic system in which consumers are identified with what they buy and what they consume. Hence when this relationship becomes unbalanced, the capitalist economic system, which mainly dominates the economies today around the world, momentously suffers a situation of crisis and paralysis. Once the basis of this view is significantly undermined and crumbled across the world, therefore, consumers finds themselves in a state of identity crisis and thus become very fragile, restless, hopeless and pessimistic about future in their lives; their existence and expectations fall apart and crumble away, leaving their place to a sense of misery and 
fragmentation in life (Jansiz, 2014).

In The Decline of the West, similarly, Kureishi represents such kind of fragmented and crippled identity through the life of Mike in the wake of his dismissal from his job in the bank. Mike, like many employees across the world, becomes the victim of the "financial crash" of 2007-2008 when "the financial system was out of control" in the British society in the early decade of the twenty-first century (Kureishi, 2010, pp. 407, 401). When the story of The Decline of the West opens, the reader learns at once the news that Mike has been fired from his job in the bank. As soon as he enters home, he appears to the reader in shock and crisis; he wants to "give his wife the news straight away", yet she does not pay attention to him but continues her life as usual (p. 401). With the crippling and disturbing feeling of his dismissal in his mind, he strives to get involved in things to remove himself from the psychological disturbance, so that he immediately gets "a frozen meal from the freezer" and puts it "in the microwave. Waiting for it to heat up, he poured himself a glass of wine" and blankly stands "at the long windows which overlooked the garden" (p. 401). Moreover, Mike cannot control himself but desires to engage himself further with other activities, so that he "switched on the garden lights and, looking out at the new deck where last summer they'd held barbecues" (p. 401), and then Mike sees "three $£ 20$ notes Imogen had left for the cleaner. Mike picked one of them up and looked at it closely. How had he never noticed what sardonic little Mona Lisa smile the blinged-up monarch wore, mocking even, as if she pitied the vanity and greed the note inspired" (p. 402). As seen in these quotations above, it is obvious that Mike seems very much confused, frustrated, fragmented and fallen apart in views because the means - job and money - which had added meaning to his life and identity in various ways have gone out of his hand, leaving him in a great limbo. He strongly feels an urgent need "to be cheered up tonight" for letting his frustrating and disturbing feeling disappear (p. 403), so that Mike endeavours to keep himself busy doing other things just to drown his sorrow. In addition, his frustration also increases further once he looks at one of $£ 20$ notes and then perceives for the first time "language" and message which communicate with him. The paper money simply stands for exchange of goods, yet at the same time it is closely associated with the power of "purchase and spending", together with a sense of who we are and of social status.

Thus, Mike, in this "sardonic" and "mocking" situation, perhaps comes to realize the real meaning lying behind the paper money: that is, the paper money is not naïve but actually a sign which provides us knowingly and unknowing with a sense of self: we are actually what we buy and what we consume, yet this sense of identity, as in the case of Mike, is a false identity in which he also becomes the victim of consumer culture under the perception that he is free and comfortable and has more options when he buys and consumes. 
Mike's crippled sense of identity may derive from three reasons. First, now he feels unable to sustain his own personal luxury and comfort. Although he had worked hard and long hours, he, like many people around the world, had enjoyed it fully. But now he comes to realize that his luxurious and comfortable life was fake and apparently subjected to fragility, so that what capitalism and consumer culture have pledged - "comfort", happiness and satisfaction - was deception and illusion. Secondly, he is a father and has responsibility for his family because his two sons and luxury addict, acquisitive wife are so demanding in their way of life and thus always want to have whatever they want - a new "guitar, an amp and a microphone", as well as " a new computer", and so on. These demands obviously put him under huge burden and pressure because he is unable to fulfil their habitually never-ending demands since he is unemployed now and is also in debt; he is psychologically intimidated and worried about his material weakness because he has already declined in his power of "buying" and "spending", even though his family does not know yet. The third reason behind his frustration and crush is also the view that Mike seems to have lost his social status and standard in society. This situation is clearly seen in his rumination, while roaming aimlessly from one room to another in his house: "there in the semi-darkness, gripping and ungripping his fist, he wondered whether he might go mad with fury. He knew he would be shut out now from the company of those he knew and liked, becoming a sort of 'disappeared"' (p. 405). As seen clearly in this quotation and in many others throughout the story, the "financial crash" causes obviously not only the collapse of the dream-like polished life, but it also gives an idea that what individuals - identity or social status- have gained through the material improvement and purchasing is not a real but a transitory and false one, so that once individuals encounter reality and lose a bit of what they have materially gained, they immediately find themselves in panic and crisis and lose their sense of security and their centre of self in life. Hence Mike realizes "how easy it was to fall...suddenly [it] would be best...to die" for making away with his psychological frustration and unhappiness instead of living in such a crippling misery and frustration of his downfall (p. 405).

Eventually "the financial crash" leads Mike and his friends to think of different alternatives until the economic downturn recovers because they seek to survive the crisis as much as possible. For example, some of Mike's colleagues state "their intention of becoming gardeners until the recession lifted; apparently the only requirements were an empty head and a desire to develop your muscles. Others had said they might be forced into teaching. Mike, at forty five, had no idea what he would do. First he had to lose everything" (p. 403). As seen in this quotation, there may be possibility to turn back to the traditional way of life in which there seems not much risk. One can earn his/her living as long as his/her muscles are strong enough 
to work. But what is so dangerous today is that people, like Mike, cannot manage to do so because their abilities are dulled and thwarted very much by the capitalist market economy in which they are considered machines to consume. Mike, for instance, has fallen apart in his view of life, as well as in "his idea of future" (p. 401), so that he cannot recover himself and decide what to do "until the recession lifted." It is loss of his sense of ability and centre, yet towards the end of the story, Mike also starts to think of finding "a smaller place, sharing the household duties, like everyone else" in life (p. 408). That Mike and his colleagues, like many other people across the world, think of alternative way of life and earning in the postmodern era because capitalism is full of its "contradictions" and thus is unreliable, fragile and vulnerable to outside negative forces. In this respect, the traditional way of life seems an alternative, even though it is not an easy option today. What was the reason which has forced the current capitalist economic to undergo crisis and recession? The answer is given by Mike in the story: “...like many people, Mike had also worried whether the present catastrophe was punishment for years of extravagance and self-indulgence; that that was the debt which had to be paid back in suffering" (p. 404; emphasis added). It is easily seen in Mike's own life, as well as in the lives of his family members. As the narrator informs the reader, for example, Mike's house is full of "paint cans, broken children's toys, a decade's worth of discarded purchases and bags of credit card receipts" (p. 405; emphasis added). Alone this quotation is, in fact, enough to show us the level and magnitude of consumption in the postmodern period.

In conclusion, consumerism in its simplistic naïve meaning is closely related to what Zygmunt Bauman (2007) calls "a happy life", and "indeed, the society of consumers is perhaps the only society in human history to promise happiness in earthly life, and happiness here and now and in every successive 'now'; in short, and instant and perpetual happiness" (p. 44). Thus, today individuals pay much attention to the charm of this temporary "happiness", so that consumerist society, entirely bound up with the view of capitalism based on the perpetual "profit", always stimulates the idea that the more we buy commodities and the more we consume them will uphold our happiness and satisfaction in life. However, consumerism, as Jean Baudrillard and Danielle Todd have argued above, is far beyond the mere act of "buying" and "consuming"; it is a way of life; it is an ideology in which commodities we buy and consume have symbolic meaning, "language" and "code" which actually not only tell us who we are as a person but also fits us into society and culture where we are judged and branded in the eyes of the others. In this respect, our identity is constantly constructed and re-constructed by what we buy and what we consume, so that we are stimulated in a perpetual way to spend more and more on commodities since they will ultimately enable us to increase not only personal happiness and satisfaction but also social status as seen in the life of Mike in The Decline of the 
West. As discussed above, on the other hand, this kind of identity and social status is subjected to be fragile and vulnerable to possible negative conditions in the economic system. As Kureishi represents it in the story through the life of Mike, possible negative economic imbalances may bring about disappointment, anger, frustration, worry about the future and a sense of weakness once the power of "buying" and "consuming" declines. When his power of "buying" and "consuming" declines, Mike immediately panics and y starts to feel lonely, desolated, and insecure and in his life, and this feeling cause him to be crippled and fragmented in his view, and relationship not only with his family members but also the people around him.

\section{References}

Andersen, R. (1995). Consumer Culture and TV Programming. Boulder: Westview Press.

Arnould, E. J. and Thompson, C J. (2005). Consumer Culture Theory (CCT): Twenty years of re search. Journal of Consumer Research, 31, 868-882.

Beaud, M. (2001). A History of Capitalism 1500-2000. New York: Monthly Review Press.

Baudrillard, J. (1990). Seduction (B. Singer, trans.). London: Macmillan.

(1998). The Consumer Society: Myths and Structures. London: Sage.

Bauman, Z. (2007). Consuming Life. Cambridge: Polity.

Braudel, F. (1979).Civilisation materielle, economieetcapitalisme, XV-XVIII Siecle [Paris: A. Colin], vol. III, Le Temps du monde.

Caylak, A. (2011, December 12). "Söz"ün "Milat"ınabaşlarken...Milat. Retrieved from http://www. milatgazetesi.com/sozun-milatina-baslarken/31214/\#.Vd8O03Htmko

Chotiudompant, S. (2013).The Representation of Consumerism and Identity Formation in Contem porary Tai Literature.MANUSYA: Journal of Humanities Regular, 16 (1), 83-96.

Cook, G. (1992). The Discourse of Advertising. London: Routledge.

Cross, G. (2000). An All-Consuming Century: Why Consumerism Won in Modern America. New York: Columbia University Press.

Dittmar, H. (2007a). Consumer Society, Identity, and Well-being: European Monographs in Social Psychology Series. (Editor: Rupert Brown). London and New York: Psychology Press.

(2007b). The Costs of Consumer Culture and the "Cage Within": The Impact of the Material "Good Life" and "Body Perfect" Ideals on Individuals' Identity and Well-Being. Psychological Inquiry, 18(1), 23-31. 


\section{A. Gunes}

Douglas, M. and Isherwood, B. (1996).The World of Goods: Towards Anthropology of Consump tion. London: Routledge.The First edition 1979.

Emerald, N. D. (2004).Consumerism, Nature, and the Human Spirit (Unpublished Master Thesis). the Virginia Polytechnic Institute and State University, Virginia.

Jansiz, A. (2014). The Ideology of Consumption: The Challenges Facing a Consumerist Society. Jour nal of Politics and Law, 7(1), 77-84.

Kasser, T., \& Kanner, A. D. (Eds.). (2004). Psychology and consumer culture: The struggle for a good life in a materialistic world. Washington, DC: APA.

Kureishi, H. (2010). Collected Stories. London: Faber \& Faber.

Lasch, C. (1979). The Culture of Narcissism: American Life in an Age of Diminishing Expectations. New York, NY: W. W. Norton \& Company, Inc.

Malpas, S. (2005). The Postmodern. London and New York: Routledge.

McCracken, G. (1990). Culture and consumption. Indianapolis: In diana University Press.

McKibben, B. (1989). The End of Nature. New York, NY: Anchor Books.

Mitcham, C. (Ed.). (2005). Encyclopaedia of Science, Technology, and Ethics. New York and Lon -don: Thomson Gale.

Peters, M. A. (2012). Neoliberalism, Education and the Crisis of Western Capitalism. Policy Futures in Education, 10(2), 134-141.

Reinhart C. and Rogoff, K. (2009).This Time is Different. Princeton: Princeton University Press.

Rose, N. (1996). Inventing ourselves: Psychology, power, and personhood. Cambridge: Cambridge University Press.

Rosenblatt, R. (Ed.) (1999). Consuming Desires: Consumption, Culture, and the Pursuit of Happiness. Washington, DC: Island Press.

Smith, A. (1986). The Wealth of Nations: Books I-III. Harmondsworth: Penguin.

Sorkin, A. R. (2010). Too Big to Fail: The Inside Story of How Wall Street and Washington Fought to Save the Financial System-and Themselves. New York: Penguin.

Stiglitz, J. E. (2010). Freefall: America, Free Markets, and the Sinking of the World Economy. New York: W.W. Norton.

Suzuki, D. (1997) .The Sacred Balance: Rediscovering Our Role in Nature. Vancouver, British Co -lumbia: Greystone Books.

Todd, D. (2012). You Are What You Buy: Postmodern Consumerism and the Construction of Self. Hohonu, 10, 48-50. 
Twitchell, J. B. (2002). Living It Up: Our Love Affairs with Luxury. New York: Columbia University Press.

Turnbull, J. and Others. (Eds.). (2010). Oxford Advanced English Dictionary of Current English (Eighth Edition). Oxford: Oxford University Press.

Vignoles, V. L., Regalia, C, Manzi, C, Golledge, J. and Scabini, E. (2006). Beyond self-esteem: The influence of multiple motives on identity construction. Journal of Personality and Social Psychology, 90, 308-333.

Wallerstein, I. (1980). Les Etatsdans, le vortex institutionnel de l'economie-monde capitaliste.Revue Internationale de Sciences sociales, 32 (4), 797-805.

Wolf, M. (2007, December 12). Why the Credit Squeeze Is the Turning Point for the World. Financial Times. Retrieved from http://www.ft.com/intl/cms/s/0/90126fca-a810-11dc-94850000779fd2ac.html\#axzz3jvMPE4mV

Wolf, M. (2010). Fixing Global Finance. Baltimore: The Johns Hopkins University Press.

World Watch Institute. (2004). State of the World 2004: The Consumer Society. New York: W. W. Norton. 